\title{
Empirical Research on the Relationships of Intellectual Capital, Organizational Learning and Technological Innovation
}

\author{
Chen Xuejin \\ College of Management \\ Zhejiang Shuren University \\ Hangzhou, China \\ chenxuejin2010@163.com
}

\author{
Yang Zhilei \\ College of Management \\ Zhejiang Shuren University \\ Hangzhou, China \\ young_2002@163.com
}

\begin{abstract}
Intellectual capital increases the value of enterprise as knowledge. Competitive advantage can't leave technological innovation, and technological innovation achieves by common development and management of knowledge and learning, in which the point of integration is organizational learning. Conclusions can be drawn through effective questionnaire investigation and analysis to more than $\mathbf{2 0 0}$ private small and medium-sized manufacturing enterprises of Zhejiang that: 1 . Intellectual capital plays a significant role in technological innovation. 2. Organizational learning plays an Intermediary role between technological innovation and intellectual capital which include human capital, structural capital and relationship capital.
\end{abstract}

Keywords-Intellectual Capital; Organizational Learning; Technological Innovation

\section{INTRODUCTION}

In the era of knowledge economy, knowledge has overstepped the traditional factors of production and become one of the most important resources of the organization, and even has become the foundation of enterprise's survival and development. Moreover, the technological innovation of the enterprise can achieve success by the bridge of knowledge. Intellectual capital is the most important part of knowledge enterprise, while knowledge is accomplished through organizational learning. Therefore, research on the relationship and effects on intellectual capital, organizational learning, technological innovation, and the intermediary role of organizational learning between intellectual capital and technical innovation has become extremely important.

\section{LITERATURE REVIEW}

Intellectual capital is the worthiest capital that makes an enterprise, an organization or a country become wealthy, it's closely related to an enterprise's sustainable competitive power (Thomas Stewar,1997). Stewar's study put forward that the intellectual capital is made up of human capital, structural capital and relationship capital. Organizational learning is the process that accommodates the changing environment the present and the future by collecting and distributing knowledge, analysis and sharing and integrating innovation. And technological innovation is that enterprise uses innovative knowledge and new technology, adopt new mode of production and management mode, improve product quality, develop new products, improve new service, occupy market and accomplish market value (Guan Jiancheng and Shi Xiaomin, 2004).

The research on the relationships between intellectual capital and technological innovation is already relatively mature home and abroad. The added value of the intellectual capital in the enterprise depends on the strength of technological innovation. In turn, once the intellectual capital substantially value, it will have a significant role in promoting the technological innovation, which can improve the level of knowledge creation and technological innovation[1] (Edvinsson \& Malone, 2001). Zou Yan and Zhang Xuehua (2009) Pointed out that intellectual capital and absorptive capacity have a direct and positive impact on the performance of technological innovation, while analyzing the mechanism of intellectual capital for technological innovation.

Intellectual capital takes a positive effect on organizational learning. In the knowledge economy, the business managers organize staff training to improve the overall quality of the staff, in the mean time, promote the organizational learning (Baker, 1992). Actually, organizational learning mainly depends on the exchange and integration of existing information, knowledge and ideas, the higher quality of the staff, the more promotion to organizational learning (Kought \& Zander, 1992). It can contribute to enhance learning capacity when the staff has more opportunities to contact with all kinds of knowledge resources (Hansen, 1999). As Hsu \& Fang's (2008) empirical research indicated, there is a positive correlation between relationship capital and organizational learning.

Organizational learning can promote technological innovation, especially in intensive industry of knowledge (Stata,1989) [2]. Organizational learning have a positive effect on technological innovation, while the key factor to affect technological innovation is the dimension of open mind ( Calantone, 2002) [3].

In addition to the direct and positive effects on the enterprise's innovation activity, organizational learning can also have indirect effects on the performance of innovation through the fully intermediary effect of knowledge creation (Zhang Ming, 2008) [4]. Marr's (2004) studies have already shown that knowledge sharing mechanism can promote the conversion between explicit knowledge and tacit knowledge, which has a significant intermediary effect in promoting the performance of enterprise by intellectual capital [5]. Hsu \& Fang (2008) believed that there is a significant relationship 
among the intellectual capital, organizational learning and technological innovation performance. Intellectual capital produces an important influence on the performance of enterprise innovation through organizational learning.

\section{RESEARCH DESIGN}

\section{A. Research hypothesis}

Based on the literature analysis above, this paper presents the following research hypothesis.

- Hypothesis H1: Intellectual capital makes a positive effect on organizational learning, which include $\mathrm{H} 1 \mathrm{a}$ Human capital makes a positive effect on organizational learning; H1b: Structural capital makes a positive effect on organizational learning; H1c: Relationship capital makes a positive effect on organizational learning.

- Hypothesis H2: Intellectual capital makes a positive effect on technological innovation performance, which include $\mathrm{H} 2 \mathrm{a}$ : Human capital makes a positive effect on technical innovation performance; $b$ : Structural capital makes a positive effect on technical innovation performance; c: Relationship capital makes a positive effect on technical innovation performance.

- Hypothesis H3: Organizational learning makes an intermediary role in the effect of intellectual capital to technological innovation performance.

\section{B. Data and sample selection}

Project group took questionnaire investigation to 315 SMEs in Hangzhou, Ningbo, Wenzhou, Taizhou and Huzhou etc. of Zhejiang province in fall 2011. These 315 SMEs cover many industries fields of machinery, metals, textiles, transport, construction, foreign trade, etc., which mainly include small and medium-sized private manufacture enterprises. In the geographic distribution, it crosses the areas of SMEs developing much better in Zhejiang. So, it can reflect the developing situation and structural factors of intellectual capital of Zhejiang SMEs objectively. 250 questionnaires were sent out and 238 questionnaires were recovered, including 219 valid questionnaires. The recovery and efficiency rate were $95.2 \%$ and $87.6 \%$, respectively.

\section{Multiple linear regression analysis}

Variable Measuring is mainly based on the Literature research, designed after integration. It uses scales of Likert5, from 1 to 5 , respectively representing "disagree", "do not quite agree", "uncertain", "inclined to agree", "agree".

The measuring of intellectual capital mainly references the master's degree thesis of Gong Li (2009). Human capital measures in four aspects including the ability and attitude of staff, the stability of staff, the investment in human capital and the ability of managers. Structural capital measures from four parts including the organizational structure, corporate culture, business processes, innovation and $R \& D$. Relationship capital measures from customer-oriented, customer loyalty, and partners.
The organizational learning measuring mainly acceding to Edmondson's, whose design is the authority in the field of organizational learning, It measures respectively from four aspects including experiment, analysis, education and training, information on migration.

The speed of new product development, innovation and success rate, The rate of new product production value, the number of patents, are used to measure the technological innovation performance, which mainly references the research of Chen Yu-fen, Chen Jin (2009).

\section{EMPIRICAL ANALYSIS}

\section{A. Reliability and Validity Analysis}

Cronbach's $\alpha$ value is used to analysis reliability here. It is generally thought that: $0.60-0.65$ is not reliable; $0.65-0.70$ is the minimum acceptable value; $0.70-0.80$ is quite good, $0.80-0.90$ is very good. The result of reliability analysis of Human capital, Structural capital, Relation-ship capital, Organizational learning and Technology innovation are $0.859,0.826,0.851,0.800$ and 0.866 respectively. The Cronbach's $\alpha$ coefficient of each variable is greater than 0.8 . That is to say, the reliability of the questionnaire is very good.

Validity refers to the degree of accuracy reflecting from actual measurement of the sample data. This study is based on the related theory, questionnaire design according to the existing empirical research, the adopted scale revised mainly refer to the domestic and foreign scholars' mature research results. Therefore, it has high content validity.

\section{B. Correlation analysis}

The correlation analysis among all dimensions of intellectual capital and organizational learning and technological innovation is shown in table II as follows:

TABLE I. CORRELATION ANALYSIS

\begin{tabular}{|c|r|r|r|r|r|}
\hline Model & $\begin{array}{c}\text { Human } \\
\text { capital }\end{array}$ & $\begin{array}{c}\text { Structural } \\
\text { capital }\end{array}$ & $\begin{array}{c}\text { Relationship } \\
\text { capital }\end{array}$ & $\begin{array}{c}\text { Organizational } \\
\text { learning }\end{array}$ & $\begin{array}{c}\text { Technology } \\
\text { innovation }\end{array}$ \\
\hline $\begin{array}{c}\text { Human } \\
\text { capital }\end{array}$ & 1 & $.666^{* *}$ & $.523^{* *}$ & $.645^{* *}$ & $.544^{* *}$ \\
\hline $\begin{array}{c}\text { Structural } \\
\text { capital }\end{array}$ & $.666^{* *}$ & 1 & $.563^{* *}$ & $.682^{* *}$ & $.593^{* *}$ \\
\hline $\begin{array}{c}\text { Relationship } \\
\text { capital }\end{array}$ & $.523^{* *}$ & $.563^{* *}$ & 1 & $.489^{* *}$ & $.455^{* *}$ \\
\hline $\begin{array}{c}\text { Organizational } \\
\text { learning }\end{array}$ & $.645^{* *}$ & $.682^{* *}$ & $.489^{* *}$ & 1 & $.546^{* *}$ \\
\hline $\begin{array}{c}\text { Technology } \\
\text { innovation }\end{array}$ & $.544^{* *}$ & $.593^{* *}$ & $.455^{* *}$ & $.546^{* *}$ & 1 \\
\hline
\end{tabular}

Data in table I shows that in 0.01 significance correlation level, each dimension of intellectual capital and organizational learning are significantly positive correlation. It verifies the hypothesis H1a, H1b, H1c and further verifies hypothesis $\mathrm{H1}$ : intellectual capital makes a positive effect on organizational learning is established.

In 0.01 significance correlation level, each dimension of intellectual capital and technology innovation are significantly positive correlation. It verifies the hypothesis $\mathrm{H} 2 \mathrm{a}, \mathrm{H} 2 \mathrm{~b}, \mathrm{H} 2 \mathrm{c}$ and further verifies hypothesis $\mathrm{H} 2$ : Intellectual capital makes a positive effect on technological innovation performance is established. 


\section{Multiple linear regression analysis}

Furthermore, verify the intermediary role of organizational learning between intellectual capital and technical innovation through the regression analysis in table II, III, IV, V.

TABLE II. REGRESSION ANALYSIS (A)

\begin{tabular}{|c|c|c|c|c|c|}
\hline \multirow{2}{*}{ Model } & \multicolumn{2}{|c|}{$\begin{array}{l}\text { Non-standardized } \\
\text { coefficients }\end{array}$} & \multirow{2}{*}{$\begin{array}{l}\text { Standardized } \\
\text { coefficients }\end{array}$} & \multirow{2}{*}{$\mathbf{t}$} & \multirow{2}{*}{ Sig. } \\
\hline & B & $\begin{array}{c}\text { standard } \\
\text { error }\end{array}$ & & & \\
\hline (Constant) & .097 & .273 & & .356 & .722 \\
\hline $\begin{array}{l}\text { Human } \\
\text { capital }\end{array}$ & .308 & .096 & .234 & 3.209 & .002 \\
\hline $\begin{array}{l}\text { Structural } \\
\text { capital }\end{array}$ & .445 & .091 & .366 & 4.878 & .000 \\
\hline $\begin{array}{c}\text { Relationship } \\
\text { capital }\end{array}$ & .155 & .080 & .127 & 1.928 & .055 \\
\hline
\end{tabular}

Independent variable: relationship capital, human capital, instruction capital

Dependent variable: technological innovation performance

TABLE III. REGRESSION ANALYSIS (B)

\begin{tabular}{|c|c|c|c|c|c|}
\hline \multirow{2}{*}{ Model } & \multicolumn{2}{|c|}{$\begin{array}{c}\begin{array}{c}\text { Non-standardized } \\
\text { coefficients }\end{array} \\
\end{array}$} & \multirow{2}{*}{$\begin{array}{l}\text { Standardized } \\
\text { coefficients }\end{array}$} & \multirow{2}{*}{$\mathbf{t}$} & \multirow{2}{*}{ Sig. } \\
\hline & B & $\begin{array}{c}\text { standard } \\
\text { error }\end{array}$ & & & \\
\hline (Constant) & .405 & .202 & & 2.006 & .046 \\
\hline $\begin{array}{l}\text { Human } \\
\text { capital }\end{array}$ & .354 & .071 & .320 & 4.983 & .021 \\
\hline $\begin{array}{c}\text { Structural } \\
\text { capital }\end{array}$ & .429 & .067 & .421 & 6.363 & .010 \\
\hline $\begin{array}{c}\text { Relationship } \\
\text { capital }\end{array}$ & .086 & .059 & .185 & 1.460 & .046 \\
\hline
\end{tabular}

Independent variable: relationship capital, human capital, instruction capital

Dependent variable: Organizational learning

TABLE IV. REGRESSION ANALYSIS (C)

\begin{tabular}{|c|c|c|c|c|c|}
\hline \multirow{2}{*}{ Model } & \multicolumn{2}{|c|}{$\begin{array}{c}\text { Non-standardized } \\
\text { coefficients }\end{array}$} & \multirow{2}{*}{$\begin{array}{l}\text { Standardized } \\
\text { coefficients }\end{array}$} & \multirow{2}{*}{$\mathbf{t}$} & \multirow{2}{*}{ Sig. } \\
\hline & B & $\begin{array}{c}\text { Standard } \\
\text { error }\end{array}$ & & & \\
\hline (Constant) & .010 & .273 & & .038 & .040 \\
\hline $\begin{array}{l}\text { Human } \\
\text { capital }\end{array}$ & .232 & .100 & .176 & 2.313 & .022 \\
\hline $\begin{array}{c}\text { Structural } \\
\text { capital }\end{array}$ & .353 & .098 & .291 & 3.585 & .030 \\
\hline $\begin{array}{c}\text { Relationship } \\
\text { capital }\end{array}$ & .136 & .080 & .111 & 1.706 & .089 \\
\hline $\begin{array}{c}\text { Organization } \\
\text { al learning }\end{array}$ & .215 & .091 & .180 & 2.354 & .019 \\
\hline \multicolumn{6}{|c|}{$\begin{array}{l}\text { Independent variable: Organizational learning, relationship capital, } \\
\text { human capital, instruction capital } \\
\text { Dependent variable: Technology innovation performance }\end{array}$} \\
\hline
\end{tabular}

From Table II, it is known that intellectual capital (including human capital, structural capital and relationship capital) is significantly correlation with technological innovation performance, and the regression coefficient is $0.234 ; 0.366$ and 0.127 respectively.

From Table III, it is known that intellectual capital is significantly correlation with organizational learning, and the regression coefficient is $0.354 ; 0.429$ and 0.086 respectively.

As seen from table IV, the $\mathrm{P}$ value of relationship capital is 0.89 , compared with table III, it is 0.46 , this shows the organizational learning plays a fully intermediary role. The $\mathrm{P}$ value of human capital and structural capital are 0.22 and 0.30 , and the $\mathrm{B}$ value of them are 0.232 and 0.353 , compared with table III, they are 0.354 and 0.429 , the value are smaller, this means the organizational learning plays a partly intermediary role. Thus indicates that organizational learning plays a role of intermediary in the relationship between intellectual capital and enterprise performance, and at the same time hypothesis $\mathrm{H} 3$ is proved.

\section{CONCLUSION}

We can draw the following conclusions from this empirical research: (1) Intellectual capital makes an effect on technological innovation performance significantly. In which, human capital and structural capital keep high significant level on both organizational learning and technological innovation performance, while the relational capital is relatively weak. (2) There is a significant positive correlation between organizational learning and technological innovation performance. (3) Organizational learning plays an intermediary role between intellectual capital and technological innovation performance.

\section{REFERENCES}

[1] Edvinsson \& Malone. "The empirical research on the effects of intellectual capital to technological innovation of Zhejiang small and medium-sized enterprise". The master degree thesis of Zhejiang Industry University, 2010.

[2] Wei Jiang, Zheng Xiaoyong. "The research on influence mechanism of relationship embedding strength on enterprise technology innovation performance--based on the intermediary regulation effect analysis of organizational learning ability". Journal of Zhejiang university. Vol 6, 2010, pp.168-180.

[3] Wu Jiaxi. "The research on relationship of corporate social responsibility and technological innovation performance: based on the perspective of organizational learning". Industrial technology economy. Vol 12, 2009, pp.99-102.

[4] Zhang Ming, Jiang Xu, Gao Shanhang. "The empirical research on organizational learning, knowledge creation and innovation performance of strategic alliance". Science of Sciences Research. Vol 8, 2008, pp.868-873.

[5] Sun Fanghua, Chen Honger. "Review in effect mechanism of intellectual capital and enterprise performance". Around Southeast Asia.Vol 6, 2009, pp.92-95. 